rison of specimens; and the sutural space of the Australian species is never so deep or concave as in its European prototype, in which also the plaits on the columella are very much less conspicuous and more oblique, the anterior one alone approaching the size of the four on $V$. anticingulatum. The spire has one sculptured whorl, fuller than in the $V$. cingulata of Germany. There is no living species like it.

Very abundant, with occasionally the $\beta$ variety and more rarely the $\alpha$ variety, perstriata, in the Tertiary sands of the Bird Rock beds, Ad. 22 to 21, less so in Ad. 23. Both varieties common in the sandy beds Ad. 24 .

XLVIII.-On a Phosphatic Deposit in the Lower Greensand of Bedfordshire. By J. F. WaLker, F.C.S., Sid. Suss. College, Cambridge*.

\title{
[Plate XIII.]
}

The Lower Greensand formation in Bedfordshire consists of extensive beds of variously coloured sands, more or less indurated into stone.

In the vicinity of Sandy there exists a conglomerate which it is proposed to discuss in this paper. A short account of this bed, by the Rev. P. B. Brodie, appeared in the 'Geological Magazine' for April. I sent a short paper on the discovery of some fossils in it to the 'Annals and Magazine of Natural History' for July; Mr. H. Seeley this month (August) also communicated his views on this bed in a letter to the Editors of that Magazine.

This conglomerate was formerly quarried for mending the roads, until two or three years since, when it was discovered that it contained nodules of phosphatic matter, for which it is at present extensively worked. At a cutting near the Potton Railway station the bed is from 9 inches to 1 foot in thickness; and the following is the section, the strata here being slightly inclined.

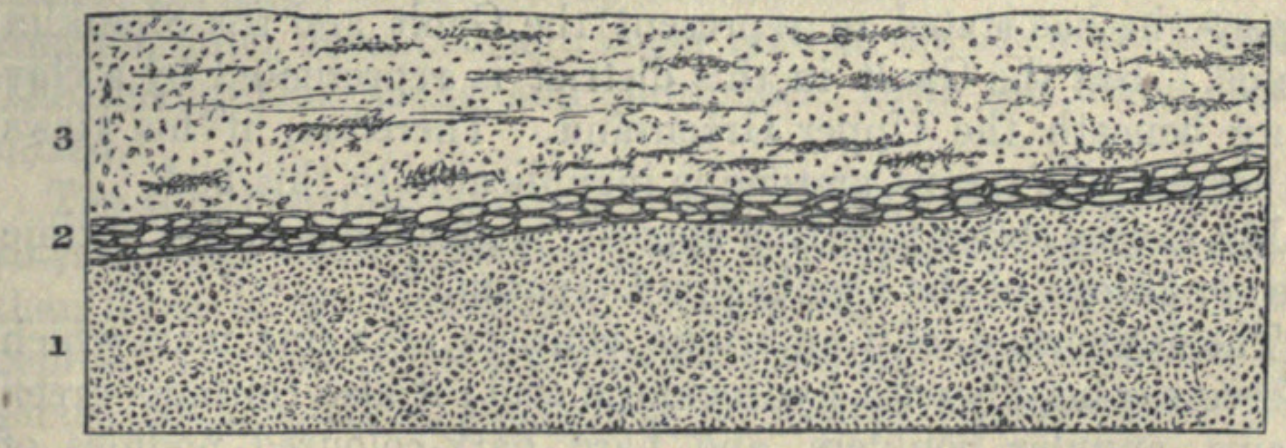

1. Sand of different colours, in some places white.

2. Conglomerate bed, 9 inches to 1 foot in thickness.

3. Sand of various colours, containing layers of oxide of iron, 12 feet.

* Communicated by the Author, having been read before the British Association, in Sections B. and C., at Nottingham, 1866. 
At a coprolite-working on the left side of the line, looking towards Cambridge, a few yards from the edge of the cutting, the bed increases in thickness to 2 feet.

At a large working on the hill the conglomerate bed is about 6 feet thick; the section is as follows :-

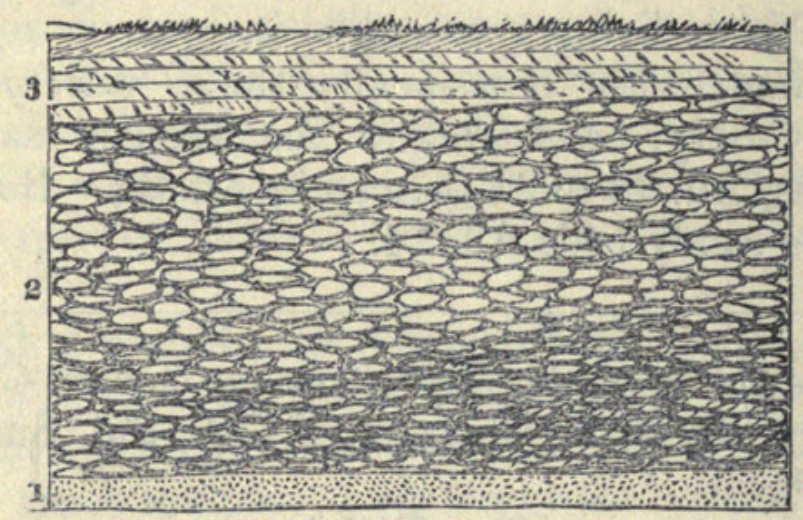

1. Sandstone, on which conglomerate rests.

2. Conglomerate bed, 6 feet.

3. Flaggy sandstone, not exceeding 1 foot in thickness (often less), and surface soil.

The lower part of the conglomerate is here darker in colour and more indurated than the upper.

On the other side of the road is another working, where the nodules lie in loose sand, and the phosphatic bed is about 1 foot thick.

There are several other workings in the neighbourhood.

The conglomerate contains phosphatic nodules and pebbles in about equal proportions. The bed is dug out and sifted, washed and laid in heaps, and then conveyed into sheds, where the nodules are picked out by hand. The quantity of phosphoric acid in the nodules varies from fifteen to twenty-two per cent.

It seems to be the opinion of Mr. H. Seeley that this bed is the southern extension of the Carstone, which, in a former paper*, he has stated to represent the Gault and the Shanklin Sands. But the Gault in this district is represented by a clay lying beneath the Upper Greensand. Therefore, if his views be correct, the term Carstone is inapplicable to this bed.

Mr. Seeley states that this deposit "reproduces earlier in time the conditions of the Cambridge Greensand."

The Greensand of Cambridge consists of a fine marl which effervesces briskly with hydrochloric acid; it also contains green grains, angular boulders, and hard dark-coloured nodules of phosphatic matter, often covered with Plicatula; lumps of iron pyrites are occasionally found. All the fossil shells are filled with the same material of which the nodules are composed.

* Quart. Journ. Geol. Soc. Nov. 1864. 
The conglomerate of the Lower Greensand of Bedfordshire consists of ferruginous sand more or less indurated (which does not effervesce with hydrochloric acid), rolled pebbles, and light-brown nodules of phosphatic matter, which have an earthy fracture and often contain fragments of shells*. The nodules are often covered with perforations, which $\mathrm{Mr}$. A. Wanklyn discovered to be the work of small bivalves $t$. Concretions of peroxide of iron are also found in this deposit.

The fossil shells found in this bed exist in two different conditions, some being casts composed of the same material as the nodules, whilst the shells of others are replaced by oxide of iron, and are filled with the same material of which the bed is composed; the indurated part of the bed also contains numerous impressions of shells. It is difficult to see how two formations presenting such marked points of difference can have been deposited under the same conditions.

The remains of organized bodies contained in this bed, as I have before stated, exist in two different states of mineralization, viz. as ferruginous shells and as phosphatic casts. The bed being very porous (a well has been sunk 50 feet deep for water) and largely impregnated with ferric oxide, shells (which, as is well known, consist chiefly of animal matter and calcic carbonate) would by the action of water have their calcic carbonate replaced by ferric oxide. In cases where the action was more rapid, only internal casts of the shells would remain.

Shells which lived in the sea whilst this bed was being formed, and also shells derived from older formations, if deposited in this bed, would undergo this change.

The phosphatic casts of shells must have been formed, or, at least, the shells must have been filled with phosphatic matter, before they were deposited here, and the calcic carbonate afterwards dissolved by the action of water. The tricalcic phosphate would be protected from the solvent action of water by the presence of calcic carbonate, as proved by the experiments of Mr. R. Warrington, junr., described in a paper read to the Chemical Society. The ferruginous shells and phosphatic casts are found intermixed.

The conglomerate contains lumps of hardened clay; and the so-called coprolites contain a much larger percentage of alumina than those of the Cambridge Greensand. The analysis of the coprolites is made from a commercial sample, which contains the shells, nodules, teeth, and bones, all ground up together. The

* In the interior of the nodules there are sometimes found specimens of a small species of Lima and of Cardium.

$\dagger$ Mr. Wanklyn has obtained several of these shells, which appear to belong to two or three different species. 
amount of alumina with the fluorine and magnesia, in one analysis, is 6.64 per cent.; of course, if a special analysis of the nodules and phosphatic casts (the adhering sand having been carefully removed) were made, the percentage of alumina would doubtless be greater. This would indicate that the phosphatic nodules had been formed of clay soaked in decomposing animal and vegetable matter, since the alumina could not be derived from either animal or vegetable sources.

The question now to be considered is, whether all the remains of organic life found in this deposit are coeval with the deposition of the bed.

$\mathrm{Mr}$. Seeley states that he has never obtained from this bed a fossil that is extraneous, and that they all appear to him to be "denizens of the old sea-bed where they abound."

There are obtained from this deposit large masses of silicified wood resembling those found in the Purbeck, also small pieces of wood mineralized with phosphoric acid, and often bored by a new species of Pholas, which I have named Pholas Dallasii.

It seems improbable that wood existing in two such different conditions should have been derived from the same source*.

Amongst the remains of animal origin we find rolled bones and teeth of reptiles and fishes, also shells of Mollusca, existing (as before mentioned) in two distinct conditions.

The phosphatic casts of shells are generally so much worn that it is impossible to identify their species with precision. In their general aspect they resemble those of the Kimmeridge and Oxford Clays. They consist of casts of Rhynchonella, of Cardium, Arca, Pholadomya, \&c., of Pleurotomaria, Chemnitzia, Natica, \&c.; three or four species of Ammonites occur, of which Ammonites biplex is found in great abundance; several of the Ammonites retain their nacreous lustre. Phragmacones of large Belemnites have also been found.

Part of the ferruginous shells also appear to have been derived from extraneous sources: amongst these I have obtained a specimen of Exogyra virgula and numerous specimens of Gryphaa dilatata. These shells, on account of their shape, could not contain phosphatic mud when they were deposited. They are in a bad state of preservation, which may be due to two causes, - first, to their having been rolled; and secoudly, to their having at the time of their deposition lost part of their animal matter; therefore the removal of their calcic carbonate would be more rapid, and its replacement by the ferric oxide less perfect.

The other ferruginous shells appear to be of the age of the

* Since this paper was read, I have obtained a fine specimen of a cone probably belonging to a Cycadaceous plant of the Wealden age. Its length is 2.6 inches, and its circumference is $2 \cdot 75$ inches. (Pl. XIII. fig. 5.) 
Lower Greensand, and do not present any traces of having been rolled. Amongst these I have determined

T. (Waldheimia) Tamarindus, Sow. Pleurotomaria DeLahayesii, D'Orb. celtica. Pecten Robinaldinus, D'Orb.

Sphæra Sedgwickii, n. sp. Ostrea macroptera, Sow.

1 have also found ferruginous casts of other shells*. I have no doubt that this list will be largely increased.

The remains of fishes seem to be principally derived from the Kimmeridge Clay. I have obtained the following species, which have also been found in the Kimmeridge Clay of Ely, specimens of which may be seen in the Woodwardian Museum and in the collection of James Carter, Esq., who kindly informed me of the occurrence of these fishes at Ely :-

Sphærodus gigas, $\mathrm{Ag}$. (Palatal teeth.) Very common.

Pycnodus, sp. (Palatal teeth.)

Gyrodus, sp. (Palates.)

Asteracanthus ornatissimus, Ag. (Dorsal spines.) Common.

Leptacanthus. (Spine.)

Hybodus, sp. (Spines and teeth.)

Sphenonchus.

Lepidotus, sp. (Scales.)

Psammodus reticulatus, Ag. (Palatal teeth.) Common.

Edaphodon, $s p$.

The remains of reptiles consist chiefly of rolled bones and teeth of Plesiosaurus and Ichthyosaurus; water-worn teeth of Pliosaurus (which reptile is characteristic of the Upper and Middle Oolites) also occur in considerable quantities. Some teeth of crocodilian character are found here as well as at Ely†.

I announced in the 'Annals of Natural History' the discovery in this bed of water-worn remains of the Iguanodon, which probably have been derived from the denudation of a deposit of Wealden which formerly existed near this district. Since then, I have obtained several more bones and teeth of this reptile. $\mathrm{Mr}$. Keeping has likewise collected some fine specimens for the Woodwardian Museum, which previously contained no fossils from this deposit.

Further evidence of the existence of the Wealden at some period in this part of England has since been obtained by Mr. Keeping, whose practical acquaintance with this formation is well known : amongst the fossils collected by him are several

* Terebratula depressa, Lamk. Exogyra cunica, Sow.

Plicatula, $s p$.

† Mr. H. Woodward, of the British Museum, kindly informed me that these teeth probably belong to a species of Dakosaurus (Quenstedt), which genus occurs in the White Jura. 
pieces of the shelly limestone containing Cyrena, which in the Wealden occurs in layers varying from 1 to 6 inches in thickness.

From a careful consideration of these facts, the conclusion seems unavoidable, that the fossils contained in this deposit consist of some coeval with its formation, and also of organic remains derived from the denudation of the Wealden and of the Kimmeridge and Oxford Clays.

The following are descriptions of the new species referred to in this paper:-

\section{Sphara Sedgwickii, n. sp. Pl. XIII. figs. 1 \& 2.}

Shell globose, nearly equilateral, slightly gibbous, concentrically striated, the striæ finer and more distinct towards the ventral margin; ligament prominent ; lunule large, distinct, cordate. This shell is very plentiful, though it is rarely found perfect. The largest specimens hitherto obtained do not exceed the following dimensions :-length 1.6 inch, breadth 1.5 inch, thickness $1 \cdot 3$ inch.

In its general form this shell closely approaches $S$. corrugata, Sby. (=Corbis cordiformis, D'Orb.); the striation of the surface, however, is much finer, especially towards the margin; the lunule is very distinctly marked. The anterior margin is also destitute of the opening at the lower end of the lunule, represented in D'Orbigny's figure. I have obtained two specimens with the valves united, which show no traces of having been rolled. The other specimens are generally more or less fragmentary.

The fossil is named in honour of the venerable Professor who first discovered Sphara corrugata.

\section{Pholas Dallasii, n. sp. Pl. XIII. figs. 3 \& 4 .}

Shell somewhat ovate, short, inflated, attenuated at the anal extremity, transversely divided by a single, nearly horizontal, punctate furrow; the surface on each side of the furrow finely striated; the striæ on the buccal side nearly parallel to the margin, those on the anal side less distinct, abbreviated, and obliquely directed towards the dorsal margin.

This little Pholas, which occurs in small pieces of wood mineralized by phosphatic salts, is very nearly allied to $P$. Cornueliana, D'Orb., from which, however, it seems to differ abundantly in its shorter form, which is more attenuated towards the anal extremity, the more horizontal direction of its single punctate furrow, and apparently the greater prominence of its umbones.

I have great pleasure in naming this fossil after my friend W. S. Dallas, Esq., F.L.S. 


\section{$2 \mathrm{BHL}$ Biodiversity Heritage Library}

Walker, J. F. 1866. "XLVIII.-On a phosphatic deposit in the Lower Greensand of Bedfordshire." The Annals and magazine of natural history; zoology, botany, and geology 18, 381-386.

View This Item Online: https://www.biodiversitylibrary.org/item/72312

Permalink: https://www.biodiversitylibrary.org/partpdf/61673

\section{Holding Institution}

University of Toronto - Gerstein Science Information Centre

\section{Sponsored by}

University of Toronto

\section{Copyright \& Reuse}

Copyright Status: NOT_IN_COPYRIGHT

This document was created from content at the Biodiversity Heritage Library, the world's largest open access digital library for biodiversity literature and archives. Visit BHL at https://www.biodiversitylibrary.org. 